\title{
Child Education and Discipline
}

\author{
Mohammad Hashim Kamali*
}

It is due largely to the Qur'an's sustained emphasis on learning ( 'ilm) that Muslim scholars explored the subjects of child education and discipline at an early stage and made significant contributions to the subject. They also placed a great deal of emphasis on virtuous conduct ( 'amal saalih), which can be seen as a concomitant aspect of Islam's outlook on education.

Leading Muslim scholars have in principle permitted light physical punishment as part of the discipline of the child, but have stressed that it should only be for a beneficial purpose, and that the parents should also be involved in any decision to apply it. When both parent and teacher agree that physical punishment is the only option they are left with, they may proceed to take that step. They are reminded, however, that the approach so taken should be disciplinary rather than punitive. Before making such a decision, teachers and parents should reflect on the purpose of punishment first. If they resort, for example, to caning, let them also make it as their last resort.

In his Adab al-Mu'allimin (The Etiquette of Teachers), Ibn Sahnun al-Tanukhi (d. $854 \mathrm{CE}$ ) took the view that caning should be restricted to three strokes. Caning the child must also be with the permission of parents and should, in any case, be moderate. Exceeding that number should be restricted to specific instances of mischief, and light strokes should in all cases apply only to safer parts of the body, such as the feet, and should in no case exceed ten strokes. Parental involvement in child discipline is meant to help the child understand that the purpose is not to inflict pain for its own sake, but to curb recurrence of deviant behaviour.

Abu'l Hasan al-Qabisi (d. 1012 CE), who authored a book on pupil-teacher relations, wrote that the best approach to discipline is to communicate with the child with kindness and concern, in an effort to identify the causes of the issue and try to appeal to the child's understanding. For the child, despite his immaturity, is a human being who is, unlike an animal, endowed with the gift of reason and the ability to know the causes of things. One should not allow anger and emotion to enter into a decision to punish a child.

Ibn Sina (d. 1037) also advocated persuasive approaches to child discipline which he felt should include not only reprimand but also encouragement and 
praise, whenever appropriate. Yet when all else fails, recourse may be had to physical punishment, preceded by a stern warning. Ibn Sina also took the unusual view that when the need arises to punish a child, let the teacher make the first punishment sufficiently painful to act as a deterrent and generate fear enough to prevent repetition.

Parents and teachers are role models for children. They are therefore advised to examine and refine their own methods in line with the socio-cultural attainments of their generation. If they don't change for the better, they should not expect their offspring and pupils to improve; negative behaviour patterns of the past are likely to persist.

Abu 'Uthman Al-Jahiz (d. 869), himself a renowned scholar, recounts that when the veteran Uqbah Ibn Abi Sufyan took his son to the teacher, he said to the teacher: "Before you start teaching my son, refurbish yourself first. This is because the students' eyes are tied to your vision. Good to them will be what you see as good, and bad to them will be what you see as bad. And be for them like a physician who does not rush in medication before diagnosing the sickness."

Abu Hamid al-Ghazali (d.1111) advised that parents and teachers should not rebuke children frequently, for recurrent admonition and rebuke may adversely affect a child's ability to respond to "gentle advice and normal communication." The basic purpose of punishment is to deter repetition and create fear through infliction of some pain. Ibn Khaldun (d. 1406) endorsed this view and warned of the harmful consequences of severity in child discipline: Severity suppresses the child and robs him of the joy of childhood, just as it is likely to encourage laziness, recourse to lying and making excuses. Parents and teachers should not overwhelm children with education such that they are deprived of time and opportunity to play games that relax them and relieve them of the fatigue of schooling. Both al-Ghazali and Ibn Khaldun advise the parents and teachers to take a minimalist approach to punishment. Should persuasive methods fail, the teacher and parent of young children ought to limit physical punishment to three strokes.

Stress management is also a factor which can help curb deviant child behaviour. When parents and teachers are able to relax, they are in a better position to contain their stress. Children and students are in even greater need for relaxation, recreation and refreshment. Reports indicate that the Prophet Muhammad, peace be upon him, and his leading Companions conducted their own study circles and sermons at suitable intervals and reduced the frequency so as to avoid weariness. The Prophet went on record to say that "the most precious gift a father or a teacher can give to a child or a student is good education."

Al-Qabisi and Ibn Sahnun suggested that students should be given the weekend in which to relax. Their education regime should not be so strict or continuous 
as to dull them with fatigue. Imam al-Ghazali used the word irhaaq, dullness of intellect, which is caused by suppressing the child with excessive learning and depriving him of play time. The child is entitled to good education as well as an enabling environment in which to learn ethical conduct (adab, tarbiyah). This combined approach to learning and tarbiyah is likely to preclude taking a facile approach to physical punishment and caning.

\title{
Notes
}

* Mohammad Hashim Kamali, Founding Chairman and CEO of IAIS Malaysia, graduated from Kabul University, and took his $\mathrm{PhD}$ in Islamic and Middle Eastern Law at the University of London in 1969. Professor Dr M.H. Kamali served as Professor of Islamic Law and Jurisprudence at the International Islamic University Malaysia (IIUM, 1985-2007), then Dean of the International Institute of Islamic Thought and Civilization (ISTAC). He also held Visiting Professorships at McGill University's Institute of Islamic Studies; Capital University, Ohio; and the Wissenschaftskolleg, Berlin. A member of the Constitution Review Commission of Afghanistan (2003), he has provided expert legal consultation to the new constitutions of Iraq, the Maldives and Somalia. Eminent authority on Islamic legal studies, he has published over 150 academic articles and 35 texts, including standard textbooks at universities worldwide.

\section{Islam, the Rule of Law and Human Rights}

\author{
Tengku Ahmad Hazri*
}

If one wishes to restore the substantive moral-spiritual foundation of the shari ${ }^{-} a h$, one must start from the premise that law precedes legislation and that the rule of law needs to go beyond any state-centred paradigm and engage greater self-governance, Human rights is one area that has always been regarded as an intrinsic component of the rule of law as can be gauged from various international documents and academic commentaries.

The United Nations Report of the Secretary-General on "The Rule of Law and Transitional Justice in Conflict and Post-Conflict Societies" defines the rule of law as "a principle of governance in which all persons, institutions and entities, public and private, including the State itself, are accountable to laws that are publicly promulgated, equally enforced and independently adjudicated, and which are consistent with international human rights norms and standards" (emphasis added). ${ }^{1}$

However, Muslim critics of human rights law consider that it is derived from "secular values and intended for a secularly-conceived man." Omar Jah and Omar Kasule have described huqūq al- 'ibād (rights of the servant (of God)) as tantamount to "the opposite of human rights". They stress that "the bureaucratic system of administering justice which is prevalent in [Muslim] 